\title{
ASSOCIATIONS AND COMMUNITIES OF CEREAL CROPS OF THE ŁUKÓW PLAIN PART I. LIGHT SOIL ASSOCIATIONS
}

\author{
Zofia Rzymowska, Teresa Skrajna \\ Department of Agricultural Ecology of the Siedlce University of Nature Sciences and Humanities, \\ B. Prusa 14, 08-110 Siedlce, Poland \\ e-mail: ekorol@uph.edu.pl
}

Received: 05.06.2011

\begin{abstract}
The characteristics of phytocenoses developing on light soils in cereal crops of the Łuków Plain are presented in the paper. The studies were carried out between 2003 and 2006 in 182 localities. Cereal crops on light soils were frequently occupied by patches of Arnoserido-Scleranthetum. The association reaches the eastern limit of its geographic range in the mesoregion. The phytocenoses were noted under various moisture conditions and were the floristically poorest cereal communities in the studied area. The paper presents new data on the occurrence of Arnoserido-Scleranthetum on its eastern distributional limits. Quite frequently, the patches of Vicietum tetraspermae scleranthetosum, especially of its variant with Juncus bufonius and Vicietum tetraspermae typicum variant with Rhinanthus serotinus, were also frequently noted in the studied mesoregion. Small patches of Papaveretum argemones were recorded very seldom.
\end{abstract}

Key words: segetal vegetation, cereal communities, Arnoserido-Scleranthetum, Papaveretum argemones, Vicietum tetraspermae

\section{INTRODUCTION}

The floristic composition of segetal communities is evidently formed under the influence of numerous biotic and anthropogenic factors. The most important are these related to habitat characteristic, e.g. soil type, its reaction, and content of nutrient elements. These factors can be considerably modified by the intensity of applied agricultural technology, especially by widespread application of herbicides and nitrogen fertilizers. The use of certified seed material and new, more fertile cereal varieties, forming dense crop stands, also visibly affect the physiognomy of these communities.

The Łuków Plain is an interesting mesoregion, because in its area Atlantic species reach their eastern geographic range.

The aim of the work was to make a phytosociological classification and floristic analysis of communities developing in cereal crops of the Łuków Plain.

\section{METHODS}

Field studies on segetal communities were carried out between 2003 and 2006 in 186 localities situated in the agricultural areas of the Łuków Plain. In total, 304 phytosociological relevés according to the Braun-Blaquet method were made in cereal crops. The phytosociological material was divided into three parts: material related to light soil communities, compact soil communities as well as transitional and impoverished communities. The present work was concerned with light soil associations and was based on the analysis of 90 phytosociological relevés. The results were summarized in phytosociological tables, of which only one, a summary table of the analysed communities, is included in the present paper. Moreover, the phytosociological constancy and cover-abundance index were calculated for each species. The classification of communities was based on the system presented by Matuszkiewicz (2007). The species nomenclature follows Mirek et al. (2002). The studied region is shown in Fig. 1. 


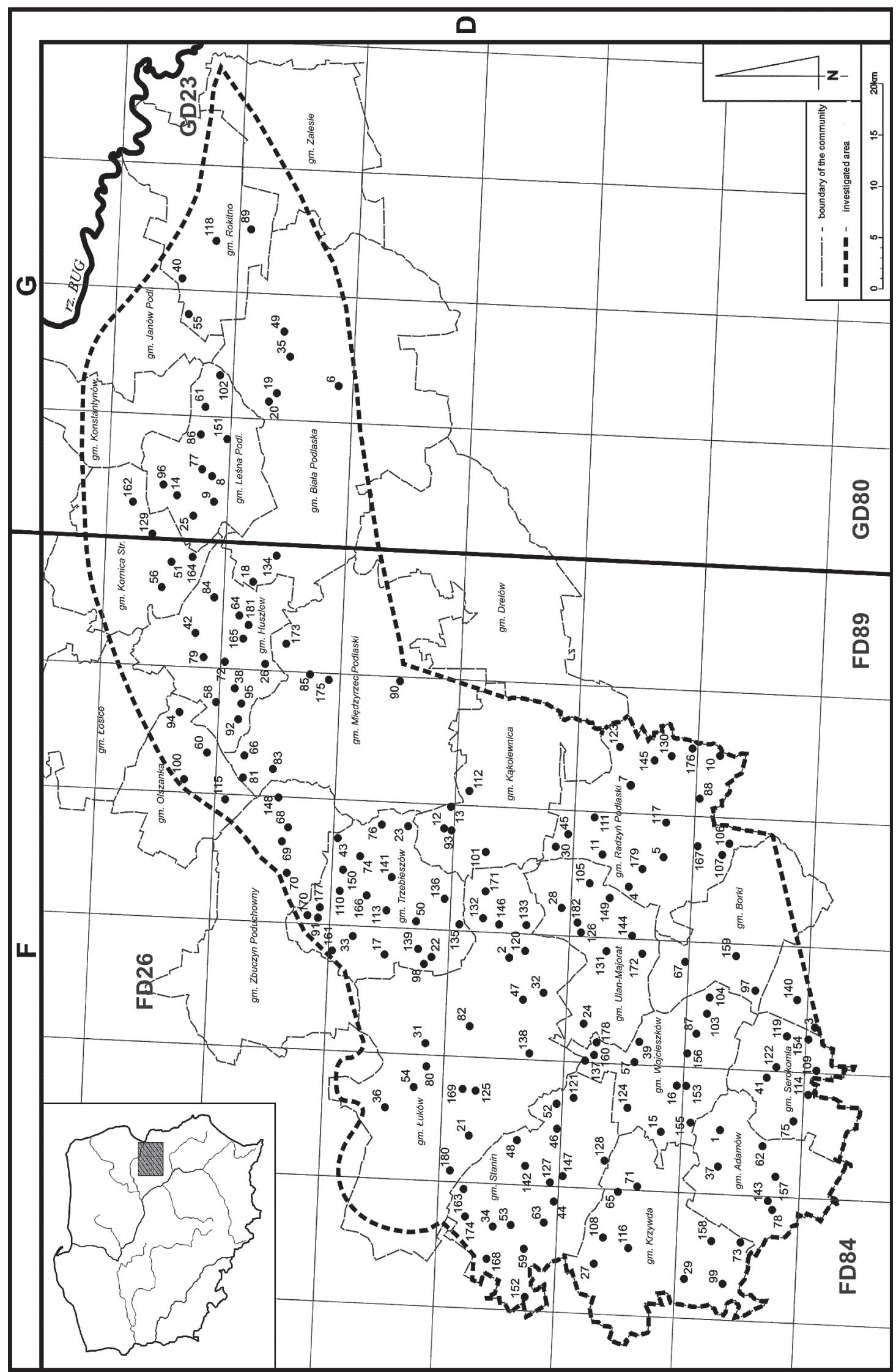

Fig. 1. Study area 
List of locations:

1 - Adamów; 2 - Aleksandrów; 3 - Annopol; 4 - Bedlno; 5 - Biała; 6 - Biała Podlaska; 7 - Białka; 8 - Bordziłówka Nowa; 9 - Bordziłówka Stara; 10 - Branica Radzyńska; 11 - Brzostówiec; 12 - Brzozowica Duża; 13 - Brzozowica Mała; 14 - Bukowice; 15 - Burzec; 16 - Bystrzyca; 17 - Celiny; 18 - Cełujki; 19 - Cicibór Duży; 20 - Cicibór Mały; 21 - Dąbie; 22 - Dębowica; 23 - Dębowierzchy; 24 - Domaszewnica; 25 - Droblin; 26 - Dziadkowskie; 27 - Fiukówka; 28 - Gąsiory; 29 - Gąszcze; 30 - Główne; 31 - Gołaszyn; 32 - Gołąbki; 33 - Gołowierzchy; 34 - Gózd; 35 - Grabanów; 36 - Gręzówka; 37 - Gułów; 38 - Harachwosty; 39 - Hermanów; 40 - Hołodnica; 41 - Hordzieżka; 42 - Huszlew; 43 - Jakusze; 44 - Jarczówek; 45 - Jaski; 46 - Jeleniec; 47 - Jeziory; 48 - Józefów; 49 - Julków; 50 - Karwów; 51 - Kiełbaski; 52- Kierzków; 53 - Kij; 54 - Klimki; 55 - Klonowica Duża; 56 - Kobylany; 57 - Kolonia Bystrzycka; 58 - Kopce; 59 - Kopina; 60 - Korczówka; 61 - Korczyska; 62 - Korzonatka; 63 - Kosuty; 64 - Kownaty; 65 - Kożuchówka; 66 - Kożuszki; 67 - Krasew; 68 - Krzesk Królowa Niwa; 69 - Krzesk Majątek; 70 - Krzesk Stary; 71 - Krzywda; 72 - Krzywośnity; 73 - Kubylczyk; 74 - Kurów; 75 - Leonardów; 76 - Leszczanka; 77 - Leśna Podlaska; 78 - Lipiny; 79 - Liwki; 80 - Ławki; 81 - Łuby; 82 - Łuków; 83 - Łuniew; 84 -Makarówka; 85 - Manie; 86 - Mariampol; 87 -Marianów; 88-Marynin; 89-Michałki; 90 - Międzyrzec Podlaski; 91 - Mikłusy; 92 - Mostów; 93 - Mościska; 94 - Mszanna; 95 - Nieznanki; 96 - Nosów; 97 - Nowiny; 98 - Nurzyna; 99 - Okrzeja; 100 - Olszanka; 101 - Olszewnica; 102 - Ossówka; 103 - Oszczepalin I; 104 - Oszczepalin II; 105 - Paskudy; 106 - Paszki Duże; 107 - Paszki Małe; 108 - Patok; 109 - Pieńki; 110 - Płudy (gm. Trzebieszów); 111 - Płudy (gm. Radzyń Podlaski); 112 - Polskowola; 113 - Popławy; 114 - Poznań; 115 - Próchenki; 116 - Radoryż Kościelny; 117 - Radzyń Podlaski; 118 - Rokitno; 119 - Ruda; 120 - Rzymy Las; 121 - Sarnów; 122 - Serokomla; 123 - Siedlanów; 124 - Siedliska; 125 - Sięciaszka; 126 - Skrzyszew; 127 - Stanin; 128 - Stara Gąska; 129 - Stara Kornica; 130 - Stasinów; 131 - Stok; 132 - Strzyżew; 133 - Sochocin; 134 - Swory; 135 - Szaniawy-Matysy; 136 - Szaniawy-Poniaty; 137 - Świderki; 138 - Świdry; 139 - Świerszcze; 140 - Talczyn; 141 - Trzebieszów; 142 - Tuchowicz; 143 - Turzystwo Drugie; 144 - Ulan Majorat; 145 - Ustrzesz; 146 - Wagram; 147 - Wesółka (gm. Stanin); 148 - Wesółka (gm. Zbuczyn); 149 - Wierzchowiny; 150 - Wierzejki; 151 - Witulin; 152 - Wnętrze; 153 - Wojcieszków; 154 - Wola Bukowska; 155 - Wola Burzecka; 156 - Wola Bystrzycka; 157 - Wola Gułowska; 158 - Wola Okrzejska; 159 - Wola Ossowińska; 160 - Wólka Domaszewska; 161 - Wólka Konopna; 162 - Wólka Nosowska; 163 - Wólka Zastawska; 164 - Wygnanki; 165 - Wygoda; 166 - Wylany; 167 - Zabiele; 168 - Zagóździe; 169 - Zalesie; 170 - Zaolszynie; 171 - Zarzecz Łukowski; 172 - Zarzecz Ulański; 173 - Zasiadki; 174 - Zastawie; 175 - Zaścianki; 176 - Zbulitów; 177 - Zembry; 178 - Zofibór; 179 - Żabików; 180 - Żdżary; 181 - Żurawlówka; 182 - Żyłki.

\section{RESULTS AND DISCUSSION}

\section{Systematics of distinguished cereal associations}

Class: Stellarietea mediae Tx., Lohm. et Prsg. 1950

Order: Centauretalia cyani R. Tx. 1950

Alliance: Aperion spicae-venti R. Tx. et J. Tx. 1960

1. Association: Arnoserido-Scleranthetum (Edouard 1925) R. Tx. 1937

- typical variant

- variant with Polygonum hydropiper

2. Association: Papaveretum argemones (Libb. 1032) Krusem. et Vlieg. 1939

3. Association: Vicietum tetraspermae (Krusem. et Vlieg. 1939) Kornaś 1950

a. Subassociation: Vicietum tetraspermae scleranthetosum

- typical variant

- variant with Juncus bufonius

b. Subassociation: Vicietum tetraspermae typicum

- variant with Rhinanthus serotinus

Characteristics of distinguished associations Arnoserido-Scleranthetum (Chouard 1925) Tx. 1937

Patches of Arnoserido-Scleranthetum were frequently found in the area of the Łuków Plain. They occupy large areas, especially in the south-western and western part of the mesoregion; this is a result of the Sub-Atlantic character of the community (F i j a ł k ow ski, 1991; W a r cholińs ka, 1995). In the eastern part of the mesoregion (the eastern limit of its geographic range), patches of Arnoserido-Scleranthetum were observed quite rarely. Very seldom was the association noted in the area of the Podlaski Przełom Bugu mesoregion, bordering on the Łuków Plain (Skrzyczýn ska and Rzy mowska, 2005). In north-eastern Poland, the community has been observed in the regions of Pojezierze Iławskie and Pojezierze Olsztyńskie (P o la k o w s ki et al. 1989; B ł o c $\mathrm{k} \mathrm{i} \mathrm{,2001).} \mathrm{It} \mathrm{has} \mathrm{never} \mathrm{been} \mathrm{noted} \mathrm{in} \mathrm{the} \mathrm{Polesie} \mathrm{region}$ (Fijałkowski et al. 2002).

The phytocenoses of Arnoserido-Scleranthetum develop in rye fields on light, acidic in reaction, pseudo-podzolic, brown leached and boggy soils, included in weak and very weak rye and weak cereal-fodder complexes (Table 1). Due to high floristic differentiation of the association (the effect of diverse moisture conditions), the typical and wet variants of the association were distinguished. Floristic differentiation of Arnoserido-Scleranthetum is rarely observed in Poland (W a r c holi ń s k a, 1995). It has been reported by the following authors: W a r cholińska (1997), Sobisz (2000), Ratuszniak and Sobisz (1999). A low degree cover-abundance of Arnoseris minima and Scleranthus annuus (species characteristic for the association) was observed in patches of the variant with Polygonum hydropiper. Apera spica-venti was noted more frequently and more abundantly. The 
occurrence of a numerous group of hygrophilous species, e.g. Polygonum hydropiper, Gnaphalium uliginosum, Mentha arvensis, and Spergularia rubra, was also noted; however, their degree of cover was low. Differential species, e.g. Veronica dillenii, Anthoxanthum aristatum, Teesdalea nudicaulis, Spergula morisonii and Holcus mollis, were seldom recorded in the analyzed plots. Only an occasional occurrence of these Sub-Atlantic species can be a result of the process of impoverishment of the patches of the association, which was described by B i elska (1989) and Błocki (2001).

The occurrence of patches of the association with dominance of Anthoxanthum aristatum is especially noteworthy. That expansive plant is considered rare in the study area, however strongly degenerated patches of Arnoserido-Scleranthetum with mass occurrence of this species were observed. They were distinguishable by species poverty and low cover degree as well as vitality of other plants. Data on dominance of Anthoxanthum aristatum in field associations and on transformation of communities under the influence of the weed plant have also reported from the adjacent areas by Skrzyczyńska et al. (2004) and S k r z y c z y ń s k a et al. (2010). Similar observations from other regions of Poland have been published by Szmeja (1994, 1996), W a r cholińska (1997), B ł o c k i (2001), and Kozak (2002).

The analyzed association was the floristically poorest cereal phytocenosis in the Łuków Plain mesoregion. On average, 11 species were noted in one relevé in typical patches and 17 in patches with Polygonum hydropiper. In total, the occurrence of as much as 89 species was observed in 47 patches of the association, 55 in typical patches and 68 in patches with Polygonum hydropiper. A large number of species noted in the community is a result of the frequent occurrence of the association in the studied area (a large number of relevés) and the occurrence of numerous apophytes coming from adjacent psammophilous grasslands.

\section{Papaveretum argemones (Libb. 1932) Krus. et Vlieg. 1939}

It is a very rare association in cereal crops of the Łuków Plain mesoregion. Small areas of phytocenoses (8 patches) were observed exclusively on field margins (Table 1). The process of withdrawal of characteristic species from crop field margins and roadsides under the influence of anthropopressure seems to be observed. Dense stands of intensive crops limit their occurrence due to the worsening of light and thermal conditions. This rare association, similarly like in the Lublin Upland (F i j a łk ow ski, 1991), develops on sandy pseudo-podzolic soils of slightly acidic and acidic reaction included in the weak rye complex. Only 52 species were noted on these soils, on average 17 species in one relevé. Apart from Papaver argemone and early spring differential species (Arabidopsis thaliana and Veronica triphyllos), such plants as Erophila verna, Myosotis stricta, and Arenaria serpyllifolia were also frequently noted (Table 1). A large proportion of acidophilus species, e.g. Scleranthus annuus, Anthemis arvensis, was also observed. Moreover, a few species characteristic for higher syntaxonomic units, e.g. Apera spica-venti and Centaurea cyanus, were noted with high cover. The phytocenoses of Papaveretum argemones were more frequently recorded in the adjacent mesoregions of the South Podlasie Lowland (S k r z y czyńska, 1994; Skrzyczyńska and Skrajn a, 2004; S krzyczyńs ka and Rzy mow ska, 2005). This association is common in the Wielkopolska region (J a ckowiak et al. 1994) as well as in southern (A ni o l-Kwiatkowska, 1990; Koz a k, 2002; W ę g r z y n e k, 2003) and central Poland (W a r c ho li ń s k a, 1974, 1997, 1998).

\section{Vicietum tetraspermae Krus. et Vlieg 1939}

Vicietum tetraspermae is the most common association in the studied area, similarly like in the other mesoregions of the South Podlasie Lowland (S k r z y czyńska, 1994; Skrzyczyńska and Skrajn a, 2004; Skrzyczyńs ka and Rzy mow ska, 2005) and in whole Poland (W ó j c i k, 1965; S i c iń ski，1974, 2003; W a rcholińska, 1974, 1997, 1999; K o zak, 2002; W ę grzyne k, 2003). It is also the most internally differentiated cereal phytocenosis in the area of the Łuków Plain. The identified subassociations and variants reflect the mosaic of trophy-moisture conditions of the studied area and the level of agriculture.

Patches of Vicietum teraspermae scleranthetosum and the typicum variant with Rhinanthus serotinus developed on light soils (Table 1). Vicietum tetraspermae scleranthetosum was diversified internally as a result of different moisture condition of habitats. Two variants: the wet variant with Juncus bufonius and the typical one were distinguished. The wet variant developed on various soil types, usually on sandy soils, formed on clayey sand and light clay, included in cereal-fodder and good rye complexes. Typical patches were noted on pseudo-podzolic and brown leached soils of weak and good rye complexes. Vicia tetrasperma and other species distinguishing the association and subassociation reached a higher cover degree in the typical variant than in the patches with the participation of hygrophilous species (wet variant) Bromus scalinus was observed sporadically in both communities, however it reached a higher cover in the patches with Juncus bufonius. The largest proportions of Juncus bufonius, Gnaphalium uliginosum, Polygonum hydropiper, Potentilla anserine, and Spergularia rubra were noted among hygrophilous species. Patches with Juncus 
bufonius were dominated by Apera spica-venti, typical patches - by Vicia hirsuta. In the analyzed subassociation, the occurrence of 92 species in total was noted, of which 48 in typical patches and 78 in wet ones. The number of species was respectively 14 (from 10 to 20) and 22 (from 17 to 29).

The Vicietum tetraspermae typicum variant with Rhinanthus serotinus was observed on various soil types included in good rye and week cereal-fodder complexes. These species-poor phytocenoses were dominated by Rhinanthus serotinus (Table 1). In total, 62 species were noted in them, on average 21 species in one relevé. Vicia tetrasperma and other species characteristic and differential for the association were frequently observed. Bromus secalinus was most frequently observed on light soils, however it never reached a high cover degree there. Among species characteristic for Aperion spicae-venti and Centauretalia cyani, a large share of Apera spica-venti was noted. Acidophilus species were noted seldom and not abundantly. On the other hand, hygrophilous species, e.g. Juncus bufonius, Gnaphalium uliginosum, Polygonum hydropiper, Polygonum amphibium, and Sagina procumbens, were noted frequently and with a large cover. The occurrence of similar phytocenoses of Vicietum tetraspermae has been reported by $\mathrm{S} \mathrm{k} \mathrm{r} \mathrm{z} \mathrm{y} \mathrm{c} \mathrm{z} \mathrm{y} \mathrm{ń} \mathrm{s} \mathrm{k} \mathrm{a}$ and S kraj n a (2004) from the Kałuszyńska Upland, by Skrajna et al. (2009) from the Mazowiecki Landscape Park, and by W ójcik (1965) from the Mazowsze region.

Table 1.

Cereal communities of light soils of the Łuków Plain

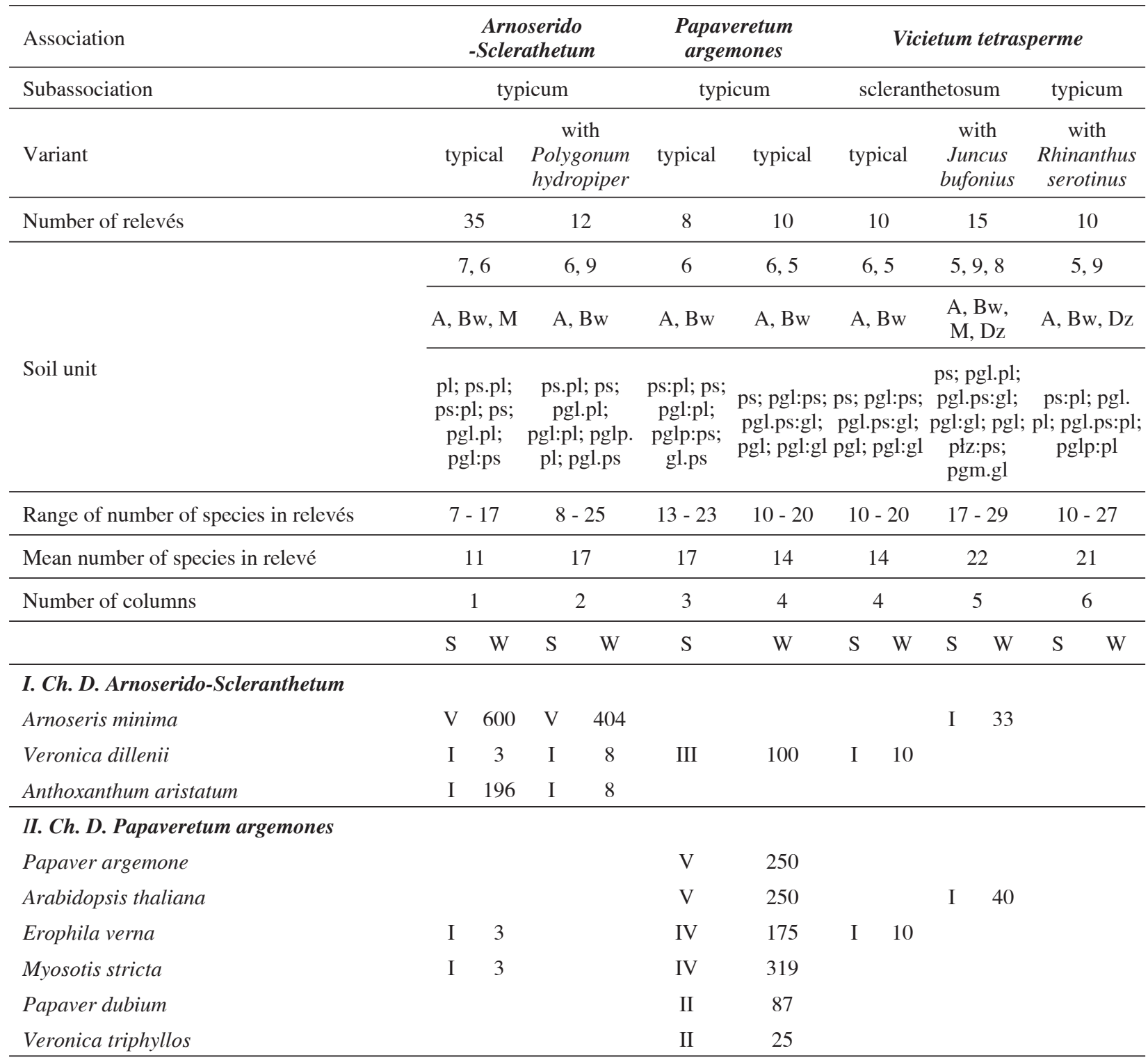




\begin{tabular}{|c|c|c|c|c|c|c|c|c|c|c|c|c|}
\hline \multicolumn{13}{|l|}{ III.Ch.D. Vicietum tetraspermae } \\
\hline Vicia tetrasperma & I & 0 & & & & & $\mathrm{~V}$ & 590 & $\mathrm{~V}$ & 343 & $\mathrm{~V}$ & 425 \\
\hline Vicia villosa & I & 17 & I & 50 & II & 37 & IV & 640 & III & 127 & III & 170 \\
\hline Bromus secalinus & & & & & & & I & 10 & I & 130 & III & 50 \\
\hline Polygonum lapathifolium subsp. pallidum & & & & & & & & & $\mathrm{I}$ & 13 & II & 70 \\
\hline \multicolumn{13}{|l|}{ IV. D. Vt scleranthetosum } \\
\hline Scleranthus annuus & $\mathrm{V}$ & 754 & $\mathrm{~V}$ & 321 & IV & 781 & $\mathrm{~V}$ & 960 & $\mathrm{~V}$ & 507 & I & 10 \\
\hline Anthemis arvensis & IV & 331 & III & 125 & $\mathrm{~V}$ & 137 & $\mathrm{~V}$ & 920 & IV & 587 & II & 30 \\
\hline \multicolumn{13}{|l|}{ V. var. z Rhinanthus serotinus } \\
\hline Rhinanthus serotinus & $\mathrm{I}$ & 46 & & & & & $\mathrm{I}$ & 60 & & & $\mathrm{~V}$ & 1225 \\
\hline \multicolumn{13}{|l|}{ VI. D. form with hygrophilous species } \\
\hline Polygonum hydropiper & & & $\mathrm{V}$ & 150 & & & & & III & 327 & IV & 230 \\
\hline Gnaphalium uliginosum & I & 3 & IV & 67 & & & & & IV & 147 & IV & 395 \\
\hline Juncus bufonius & & & II & 100 & I & 12 & & & IV & 537 & IV & 810 \\
\hline Spergularia rubra & & & III & 83 & & & & & II & 120 & I & 20 \\
\hline Mentha arvensis & & & III & 221 & & & & & II & 40 & I & 20 \\
\hline Polygonum amphibium & & & & & & & & & I & 40 & III & 90 \\
\hline Gypsophila muralis & & & I & 50 & I & 12 & I & 10 & II & 93 & & \\
\hline Hypericum humifusum & & & II & 125 & & & & & I & 33 & & \\
\hline Equisetum sylvaticum & & & II & 25 & & & & & & & & \\
\hline Sagina procumbens & & & I & 17 & & & & & I & 40 & II & 245 \\
\hline Bidens tripartita & & & I & 8 & & & & & I & 7 & II & 40 \\
\hline Stachys palustris & & & I & 17 & & & & & & & II & 30 \\
\hline Potentilla anserina & & & & & & & & & II & 190 & I & 60 \\
\hline Plantago intermedia & & & & & & & & & II & 67 & & \\
\hline
\end{tabular}

VII. Ch. Aperion spicae-venti, Centaureatalia cyani

\begin{tabular}{|c|c|c|c|c|c|c|c|c|c|c|c|c|}
\hline Apera spica-venti & IV & 184 & $\mathrm{~V}$ & 479 & IV & 781 & III & 420 & V & 1113 & IV & 685 \\
\hline Centaurea cyanus & III & 57 & III & 42 & $\mathrm{~V}$ & 350 & $\mathrm{~V}$ & 290 & III & 357 & III & 50 \\
\hline Vicia angustifolia & II & 29 & II & 33 & I & 62 & III & 60 & IV & 73 & II & 80 \\
\hline Vicia hirsuta & I & 3 & I & 17 & II & 75 & IV & 1005 & III & 330 & II & 70 \\
\hline Matricaria maritima subsp.inodora & I & 6 & & & & & II & 70 & I & 40 & I & 10 \\
\hline \multicolumn{13}{|l|}{ VIII. Ch. Stellarietea mediae } \\
\hline Conyza canadensis & III & 141 & II & 58 & $\mathrm{~V}$ & 187 & III & 90 & II & 53 & III & 50 \\
\hline Spergula arvensis & III & 147 & $\mathrm{~V}$ & 200 & I & 12 & I & 10 & II & 33 & II & 30 \\
\hline Viola arvensis & IV & 74 & II & 33 & III & 50 & IV & 160 & III & 80 & II & 40 \\
\hline Chenopodium album & I & 11 & III & 50 & I & 12 & I & 10 & II & 40 & III & 50 \\
\hline Fallopia convolvulus & I & 14 & I & 8 & II & 25 & II & 40 & II & 27 & IV & 70 \\
\hline Polygonum aviculare & I & 6 & II & 17 & & & & & III & 47 & II & 30 \\
\hline Galeopsis tetrahit & & & III & 42 & & & I & 10 & II & 27 & II & 30 \\
\hline Myosotis arvensis & I & 6 & I & 8 & II & 37 & II & 70 & II & 60 & III & 100 \\
\hline Stellaria media & & & & & & & I & 10 & II & 60 & III & 140 \\
\hline Raphanus raphanistrum & I & 11 & II & 33 & II & 25 & & & I & 2 & I & 20 \\
\hline Setaria pumila & I & 14 & II & 67 & I & 12 & I & 10 & I & 7 & & \\
\hline Capsella bursa-pastoris & & & & & I & 12 & I & 10 & & & II & 30 \\
\hline Geranium pusillum & & & & & I & 12 & & & & & II & 30 \\
\hline
\end{tabular}




\begin{tabular}{lccccccccccccc}
\hline IX. Accompanying species & & & & & & & & & & & \\
Rumex acetosella & V & 430 & V & 396 & II & 75 & IV & 140 & IV & 367 & III & 60 \\
Equisetum arvense & II & 29 & II & 67 & III & 100 & I & 20 & IV & 153 & II & 30 \\
Arenaria serpyllifolia & I & 6 & & & IV & 481 & I & 10 & & & I & 20 \\
Convolvulus arvensis & II & 73 & II & 25 & & & III & 60 & II & 150 & I & 10 \\
Agropyron repens & I & 11 & III & 42 & I & 12 & I & 10 & II & 33 & I & 10 \\
Veronica arvensis & I & 17 & I & 8 & I & 12 & II & 30 & II & 40 & III & 50 \\
Cirsium arvense & & & I & 8 & & & & & II & 60 & II & 40 \\
Trifolium arvense & & & & & II & 494 & II & 20 & I & 7 & & \\
Achillea millefolium & & & II & 33 & I & 0 & I & 10 & I & 13 & II & 30 \\
Erodium cicutarium & I & 6 & I & 8 & II & 37 & I & 10 & I & 20 & & \\
Berteroa incana & I & 3 & & & II & 0 & I & 0 & & & & \\
Agrostis stolonifera & I & 26 & I & 42 & I & 12 & & & II & 53 & I & 10 \\
Artemisia vulgaris & I & 9 & & & I & 12 & I & 10 & II & 20 & I & 10 \\
Polygonum persicaria & I & 11 & I & 8 & & & & & I & 13 & II & 30 \\
Cerastium holosteoides & & & I & 8 & I & 12 & I & 20 & I & 20 & II & 40 \\
Poa annua & & & I & 8 & & & & & II & 53 & I & 10 \\
Trifolium repens & & & I & 8 & & & & & I & 13 & II & 80 \\
Artemisia campestris & I & 3 & & & & & & II & 10 & & & \\
\hline
\end{tabular}

\section{REFERENCES}

Anioł-Kwiatkowska J., 1990. Zbiorowiska segetalne Wału Trzebnickiego. Florystyczno-ekologiczne studium porównawcze. / Segetal communities of Wał Trzebnicki. Floristic and ecological comparative study. Wyd. Uniw. Wr. Pr. Bot.: 46-230. (in Polish)

Biels k a T., 1989. Zespół Arnoserido-Scleranthetum (Chouard 1925) Tüxen 1937 w północnej Lubelszczyźnie. / The Arnoserido-Scleranthetum (Chouard 1925) Tüxen 1937 association in the northern Lublin region (eastern Poland). Fragm. Flor. et Geobot. Ann. XXXIV, Pars 1-2: 163-167. (in Polish)

Błocki K., 2001. Nowe stanowisko Anthoxanthum aristatum Boiss. w uprawie zbóż na Pojezierzu Olsztyńskim. / A new locality of Anthoxanthum aristatum Boiss. in cereal crops in the Olsztyn Lake District. Acta Agrobot. 54(2): 141-150. (in Polish)

Fijałkowski D., 1991. Zespoły roślinne Lubelszczyzny. Wyd. UMCS Lublin: 1-303. (in Polish)

Fijałkowski D., Andrijenko T., Onyszczenko W., Święs F., Urban D., 2002. Ekosystemy lądowe leśne, kserotermiczne i synantropijne Polesia (Flora i fitocenozy). / Terrestrial and forest, xerothermic, and synanthropic ecosystems and the flora of Polesie. Acta Agrophysica, 66: 147-177. (in Polish)

Jackowiak B., Chmiel J., Latowski K., 1994. Zbiorowiska segetalne zbóż ozimych Wielkopolski. Cz. II. / Segetal communities in winter cereal crops of the Wielkopolska Region. Part. II. Bad. Fizjogr. nad Polską Zach., Botanika, 43: 105-123. (in Polish)
Kozak M., 2002. Zbiorowiska segetalne gminy Rudniki (województwo opolskie) / Segetal communities in the Rudniki municipality area (Opole Voivodship). Fragm. Flor. Geobot. Polonica, 9: 219-272. (in Polish)

Matuszkiewicz W., 2007. Przewodnik do oznaczania zbiorowisk roślinnych Polski. Vademecum geobotanicum Państwowe Wydawnictwo Naukowe, Warszawa: 537 (in Polish)

Mirek Z., Piękoś-Mirkowa H., Zając A. \& Zając M., 2002. Flowering plants and pteridophytes of Poland - a checklist. - Biodiversity of Poland, Z. Mirek (ed.) 1: 442. [In:]. Szafer Institute of Botany, Polish Academy of Sciences, Kraków.

Polakowski B., Korniak T., Hołdyński Cz., 1989. Zespół Arnoserido-Scleranthetum (Chouard 1925) Tx. 1937 w północno-wschodniej części Polski. / The association Arnoserido-Scleranthrtum (Chouard 1925) Tx. 1937 in the north-eastern part of Poland. Zesz. Nauk. WSR-P w Siedlcach, ser. Rolnictwo, 20: 196-204. (in Polish)

Ratuszniak I., S obisz Z., 1999. Zbiorowiska segetalne Parku Krajobrazowego „Dolina Słupi” Cz. I. / Segetal communities of the „Słupia River Valley” Landscape Park. Part. I. Bad. Fizjograf nad Polską Zach. Ser. B Botanica: 48: 97-110. (in Polish)

S i c ińs k i J . T., 1974. Zbiorowiska segetalne Kotliny Szczercowskiej (Widawskiej). / Segetal communities of the Szczerców Valley (Widawa Valley). Acta Agrobot. 27(2): 5-94. (in Polish)

Siciński J.T., 2003. Agrofitocenozy dorzecza środkowej Warty i Bzury - stan, dynamika i zagrożenia. / 
Agrophytocenoses of the middle Warta and Bzura river basin - the present state, dynamics, and threats. Wyd. UŁ. Rozp.: 1-69. (in Polish)

Skrajna T., Skrzyczyńska J., Ługowska M., 2009. Segetal communities of cereal crops of the Mazowiecki Landscape Park. Acta Agrobot., 62(1): 171-186.

Skrz y c z y ń ska J ., 1994. Studia nad florą i zbiorowiskami segetalnymi Wysoczyzny Siedleckiej. Wyd. WSR-P w Siedlcach. Rozp. 39: 5-145. (in Polish)

Skrzyczyńska J., Rzymowska Z ., 2005. Zbiorowiska roślinne pól uprawnych Podlaskiego Przełomu Bugu. Cz. I. Zespoły zbożowe. / Plant communities of cultivated fields of Podlaski Przełom Bugu. Part. 1. Communities of cereal crops. Acta Agrobot. 58(1): 255290. (in Polish)

Skrzyczyńska J., Skrajna T., 2004. Zbiorowiska polne Wysoczyzny Kałuszyńskiej. Cz. I. Zespoły zbożowe. / Field communities of the Kałuszyńska Upland. Part. 1. Communities of cereal crops. Fragm. Agronom. 4(84): 33-43. (in Polish)

Skrzyczyńska J., Skrajna T., Ciosek M.T.,2004. Anthoxanthum aristatum Boiss. ekspansywny gatunek Wysoczyzny Kałuszyńskiej. I Anthoxanthum aristatum Boiss. - an expansive species of the Kałuszyńska Upland. Acta Agrobot. 57(1-2): 239-253. (in Polish)

Skrzyczyńska J., Skrajna T., Rzymowska Z., 2010. Ekspansja Anthoxanthum aristatum Boiss. w uprawach rolniczych na Nizinie Południowopodlaskiej. / Expansion of Anthoxanthum aristatum Boiss. in crop fields of the South Podlasie Lowland. Fragm. Agronom. 27(2): 135-144. (in Polish)

S obis z Z., 2000. The occurrence of Arnoserido-Scleranthetum (Chouard 1925) R.Tx. 1937 in the Słowiński National Park. Baltic Coastal Zone 4: 95-103.

Sz meja K., 1994. Roślinność pól uprawnych Zaborskiego Parku Krajobrazowego. / Farmland vegetation of the Zaborski Landscape Park. Fragm. Flor. Geobot., Ser. Polonica, 1: 157-180. (in Polish)

S z me ja K., 1996. Effect of Anthoxanthum aristatum Boiss. on the density of a rye stand. Pol. Ecol Stud. 22(1-2): 3-16.

Warcholińska A.U., 1974. Zbiorowiska chwastów segetalnych Równiny Piotrkowskiej i jej współczesne przemiany w związku z intensyfikacją rolnictwa (Mezoregion Nizin Środkowopolskich. / Communities of segetal weeds of the Piotrków Plain and its modern transformations in connection with agriculture intensification (The Central Poland Lowlands Mesoregion). Acta Agrobot. 27(2): 95-194. (in Polish)

Wa rcholińs k a U., 1995. Arnoserido-Scleranthetum annui (Chouard 1925) R.Tx. 1937 corr. Matuszkiewicz 1981 em. Warcholińska 1990 in Poland. Thaiszia. J. Bot., Košice, 5: 81-96.
Warcholińska A.U., 1997. Flora i roślinność segetalna Sulejowskiego Parku Krajobrazowego. Cz. II. Roślinność segetalna. / Flora and segetal vegetation of the Sulejów Landscape Park. Part. II. Segetal vegetation. Acta Agrobot. 50(1-2): 181-202. (in Polish)

Warcholińska A.U., 1998. Papaveretum argemones (Libb. 1932) Krusem. et Vlieg. 1939 in Poland. Phytocoenosis. Suppl. Cartogr. Geobot. 9: 131 - 144.

Warcholińska A.U., $1999 . \quad$ Vicietum tetraspermae (Krusem. et Vlieg.) Kornaś 1950 w Polsce / Vicietum tetraspermae in Poland. Fragm. Flor. Geobot. Ser. Polonica, 6: $95-117$.

Węgrzynek B., 2003. Roślinność segetalna Wyżyny Śląskiej. Cz. 2. Zbiorowiska chwastów upraw zbożowych ze związku Aperion spicae-venti. / The segetal vegetation of the Silesian Upland. Part. 2. Cereal weed communities of Aperion spicae-venti alliance. Acta Biologia Silesiana, Pr. Nauk. Uniw. Śląskiego w Katowicach, 37(54) : 87-119. (in Polish)

Wójcik Z., 1965. Les associations des chaps cultives en Masovie. I-ere partie: Les associations messicoles. Ekol. Pol. Ser. A, 13(30): 642-682 (in French)

\section{Zespoły i zbiorowiska upraw zbożowych Równiny Łukowskiej Cz. I. Zespoły gleb lekkich}

\section{Streszczenie}

Praca przedstawia charakterystykę zbiorowisk chwastów wykształcających się w uprawach zbożowych na glebach lekkich Równiny Łukowskiej. Badania prowadzono w latach 2003-2006 na terenie 182 miejscowości. Na glebach lekkich badanego terenu najczęściej notowano płaty Arnoserido-Scleranthetum, zespołu osiągającego na badanym terenie wschodnią granicę zasięgu występowania. Fitocenozy takie wykształcały się w różnych warunkach uwilgotnienia i były najuboższymi florystycznie zbiorowiskami zbożowymi analizowanego terenu. Prezentowana praca poszerza wiedzę nad występowaniem Arnoserido-Scleranthetum na wschodnich krańcach jego zasięgu. Dość często na badanym terenie spotykano też płaty Vicietum tetraspermae scleranthetosum zwłaszcza wariantu z Juncus bufonius oraz Vicietum tetraspermae typicum wariantu $\mathrm{z}$ Rhinanthus serotinus, które też wykształcały się w warunkach nadmiernego uwilgotnienia. Natomiast bardzo rzadko i na niewielkich powierzchniach notowano płaty Papaveretum argemones. 